\title{
Copper deficiency can limit nitrification in biological rapid sand filters for drinking water production
}

Wagner, Florian Benedikt; Nielsen, Peter Borch; Boe-Hansen, Rasmus; Albrechtsen, Hans-Jørgen

Published in:

Water Research

Link to article, DOI:

10.1016/j.watres.2016.03.025

Publication date:

2016

Document Version

Peer reviewed version

Link back to DTU Orbit

Citation (APA):

Wagner, F. B., Nielsen, P. B., Boe-Hansen, R., \& Albrechtsen, H-J. (2016). Copper deficiency can limit nitrification in biological rapid sand filters for drinking water production. Water Research, 95, 280-288. https://doi.org/10.1016/j.watres.2016.03.025

\section{General rights}

Copyright and moral rights for the publications made accessible in the public portal are retained by the authors and/or other copyright owners and it is a condition of accessing publications that users recognise and abide by the legal requirements associated with these rights.

- Users may download and print one copy of any publication from the public portal for the purpose of private study or research.

- You may not further distribute the material or use it for any profit-making activity or commercial gain

- You may freely distribute the URL identifying the publication in the public portal 


\section{Copper deficiency can limit nitrification in biological rapid sand filters}

\section{2 for drinking water production}

3 Florian Benedikt Wagner ${ }^{a^{*}}$, Peter Borch Nielsen ${ }^{b}$, Rasmus Boe-Hansen ${ }^{b}$, Hans-Jørgen Albrechtsen ${ }^{a}$

$4 \quad{ }^{a}$ Department of Environmental Engineering, Technical University of Denmark, Miljøvej 113, 2800 Kgs. Lyngby, Denmark

$5 \quad{ }^{b}$ Krüger A/S, Gladsaxevej 363, 2860 Søborg, Denmark

6 *Corresponding author. Tel.: +45 45251478. E-mail address: flowa@env.dtu.dk (F.B. Wagner).

7

8 Keywords

9 Ammonium, Biological filtration, Copper, Drinking water, Nitrification, Nutrient limitations

\section{Abstract}

12 Incomplete nitrification in biological filters during drinking water treatment is problematic, as it compromises

13 drinking water quality. Nitrification problems can be caused by a lack of nutrients for the nitrifying

14 microorganisms. Since copper is an important element in one of the essential enzymes in nitrification, we

15 investigated the effect of copper dosing on nitrification in different biological rapid sand filters treating

16 groundwater. A lab-scale column assay with filter material from a water works demonstrated that addition of a

17 trace metal mixture, including copper, increased ammonium removal compared to a control without addition.

18 Subsequently, another water works was investigated in full-scale, where copper influent concentrations were

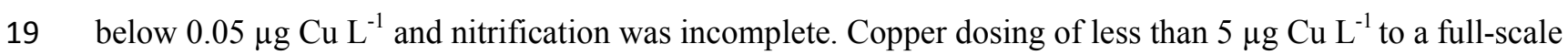

20 filter stimulated ammonium removal within one day, and doubled the filter's removal from 0.22 to $0.46 \mathrm{~g} \mathrm{NH}_{4}-\mathrm{N}$

$21 \mathrm{~m}^{-3}$ filter material $\mathrm{h}^{-1}$ within 20 days. The location of ammonium and nitrite oxidation shifted upwards in the

22 filter, with an almost 14-fold increase in ammonium removal rate in the filter's top $10 \mathrm{~cm}$, within 57 days of 


1

dosing. To study the persistence of the stimulation, copper was dosed to another filter at the water works for 42 days. After dosing was stopped, nitrification remained complete for at least 238 days. Filter effluent concentrations of up to $1.3 \mu \mathrm{g} \mathrm{Cu} \mathrm{L}{ }^{-1}$ confirmed that copper fully penetrated the filters, and determination of copper content on filter media revealed a buildup of copper during dosing. The amount of copper stored on filter material gradually decreased after dosing stopped; however at a slower rate than it accumulated. Continuous detection of copper in the filter effluent confirmed a release of copper to the bulk phase. Overall, copper dosing to poorly performing biological rapid sand filters increased ammonium removal rates significantly, achieving effluent concentrations of $<0.01 \mathrm{mg} \mathrm{NH}_{4}-\mathrm{N} \mathrm{L}^{-1}$, and had a long-term effect on nitrification performance.

\section{Introduction}

During treatment of groundwater for drinking water production, ammonium is commonly removed through nitrification in biological rapid sand filters. Nitrification is a two-step process: ammonia oxidizing archaea (Martens-Habbena and Stahl, 2011) and bacteria oxidize ammonia to nitrite, which is further oxidized to nitrate by nitrite oxidizing bacteria (Prosser, 1989). The presence of nitrifying organisms in biological groundwater

filters is well established (de Vet et al., 2011; Gülay et al., 2014; Lee et al., 2014).

Even though biological filters are commonly used to remove ammonium, nitrification is sometimes incomplete (Lee et al., 2014), leaving ammonium residues in the finished water. This is problematic for the drinking water quality, since incomplete nitrification can lead to biological aftergrowth in non-disinfected distribution systems (Rittmann et al., 2012), which can involve oxygen depletion, taste and odor problems, material corrosion, and accumulation of the toxic intermediate nitrite (Lytle et al., 2007). In chloraminated distribution systems, nitrification may decrease the disinfectant residual, thereby increasing bacterial regrowth potential and the risk of violating disinfectant residual standards (Zhang et al., 2009). In systems without disinfection during drinking 5 water distribution, biologically stable drinking water is achieved by maintaining low nutrient levels in the 
46 finished water. For example, the EU drinking water directive specifies a guideline for ammonium of $0.5 \mathrm{mg} \mathrm{NH}$

$47 \quad \mathrm{~L}^{-1}$. The EU member states are allowed to establish stricter values; as for instance Denmark, where water works

48 effluent guidelines for ammonium and nitrite are $0.05 \mathrm{mg} \mathrm{NH}_{4} \mathrm{~L}^{-1}\left(0.039 \mathrm{mg} \mathrm{NH}_{4}-\mathrm{N} \mathrm{L}^{-1}\right)$ and $0.01 \mathrm{mg} \mathrm{NO}_{2} \mathrm{~L}^{-1}$

49 (0.003 $\left.\mathrm{mg} \mathrm{NO}_{2}-\mathrm{N} \mathrm{L}^{-1}\right)$, respectively (Miljøministeriet, 2014).

50 To achieve low effluent concentrations of ammonium and nitrite, nitrifying microorganisms need an adequate

51 amount of nutrients for growth and activity, to be available during water treatment in biological filters.

52 Otherwise, nitrification can be incomplete. For example lack of phosphorus can limit nitrification in groundwater 53 treatment (de Vet et al., 2012). Besides phosphorus, nitrifiers also need trace metals for growth and activity,

54 albeit required in comparably low concentrations. Earlier studies (Ensign et al., 1993; Pedroni et al., 1997)

55 indicated the particular importance of copper for nitrification. The activity of the enzyme ammonia

56 monooxygenase, which catalyzes the first step in the oxidation of ammonia to nitrite, was greatly increased in

57 vitro under addition of copper (Ensign et al., 1993). Additionally, the loss of enzyme activity in vivo under

58 addition of copper-selective chelators (e.g. allylthiourea), emphasizes the requirement of copper for ammonia

59 monooxygenase (Sayavedra-Soto and Arp, 2011). Both ammonia oxidizing bacteria (Arp et al., 2007) and

60 archaea (Leininger et al., 2006) have the genetic inventory to express this enzyme.

61 Processes such as copper complexation and adsorption in soil, copper sulfide formation under reducing

62 conditions in anoxic groundwater, or low copper content in aquifer material (Adriano, 1986) can lead to

63 decreased concentrations of copper in groundwater for drinking water production. During treatment in biological

64 rapid sand filters, water phase concentrations can be further reduced due to copper sorption to iron-oxide

65 (Benjamin et al., 1996) and manganese-oxide coated sand (Han et al., 2006), which may decrease the availability

66 of copper for nitrifying microorganisms in the filters. Complexation with organic and/or inorganic ligands

67 (Sylva, 1976), substrate diffusion limitations, and competition for nutrients by other microorganisms in the filter

68 (de Vet et al., 2011) can further decrease copper availability. 
69 At present, only little is known about copper deficiency in biological rapid sand filters for groundwater treatment 70 and its importance for limitations of nitrification activity. Therefore, we investigated the effect of copper dosing 71 on nitrification activity in potentially copper limited biological rapid sand filters. Specific questions were:

- Can dosing of copper to the influent water of biological filters, subject to incomplete nitrification, stimulate the removal of ammonium and nitrite?

- How fast does ammonium removal increase, and what is the corresponding magnitude of dosed copper? How persistent is the effect of copper dosing after it has been stopped?

- How are ammonium and nitrite removal patterns over filter depth affected by the dosing? What is the increase in removal capacity for ammonium at certain depths of a filter?

Two approaches were used in the study: (1) the potential of a trace metal mixture containing copper to stimulate ammonium removal was investigated employing a lab-scale column assay, and (2) the effect of controlled copper dosing on nitrification was examined with water and sand depth-sampling of two full-scale filters, in a 280 day comprehensive study at a groundwater treatment plant.

\section{Materials and Methods}

\subsection{Lab-scale study with trace metals}

Potential stimulation of ammonium removal by addition of a broad mixture of trace metals was investigated in a lab-scale column assay (Tatari et al., 2013), under controlled conditions. The assay uses lab-scale columns, packed with full-scale filter media, and operated inside a refrigerator, in order to match the temperature at the water treatment plant. Complete mixing in the assay prevents stratification of nitrification activity in the columns (Tatari et al., 2013), which makes it possible to reproduce depth-specific nitrification kinetics of a full-scale filter media sample. 
91 Filter media from a secondary biological rapid sand filter (filter number 4) at Langerød full-scale groundwater

92 treatment plant (GWTP), Denmark, was used. Anoxic groundwater with high alkalinity (Table 1) is treated at

93 this plant with simple stairs aeration and a de-ironing primary sand filter, followed by two secondary biological

94 filters in parallel. The secondary filters have been suffering from incomplete nitrification for several years. With

95 effluent concentrations of $0.32 \mathrm{mg} \mathrm{NH}_{4}-\mathrm{N} \mathrm{L}^{-1}$, the filters remove only approx. $50 \%$ of the influent ammonium

96 (Table 1).

Table 1: Water quality characteristics along the treatment at groundwater treatment plants (GWTP)

\begin{tabular}{|c|c|c|c|c|c|c|}
\hline & \multicolumn{3}{|c|}{ Langerød GWTP } & \multicolumn{3}{|c|}{ Nærum GWTP } \\
\hline & $\begin{array}{c}\text { Raw } \\
\text { water }\end{array}$ & $\begin{array}{c}\text { Secondary } \\
\text { filter } \\
\text { influent } \\
\end{array}$ & $\begin{array}{c}\text { Secondary } \\
\text { filter } \\
\text { effluent }\end{array}$ & $\begin{array}{c}\text { Raw } \\
\text { water }\end{array}$ & $\begin{array}{c}\text { Filter } \\
\text { influent }\end{array}$ & $\begin{array}{c}\text { Filter effluent } \\
\text { (before Cu } \\
\text { dosing) }\end{array}$ \\
\hline Temp $\left[{ }^{\circ} \mathrm{C}\right]$ & 9.1 & 9.3 & 9.3 & 9.2 & 9.6 & 9.6 \\
\hline $\mathrm{pH}[-]$ & 7.4 & 7.6 & 7.7 & 7.5 & 7.7 & 7.6 \\
\hline Dissolved oxygen $\left[\mathrm{mg} \mathrm{L}^{-1}\right]$ & 0.3 & 10.2 & 9.1 & $<0.1$ & 9.8 & 8.9 \\
\hline $\mathrm{NH}_{4}^{+}\left[\mathrm{mg} \mathrm{N} \mathrm{L}^{-1}\right]$ & 1.09 & 0.62 & 0.32 & 0.35 & 0.34 & 0.17 \\
\hline $\mathrm{NO}_{2}^{-}\left[\mathrm{mg} \mathrm{N} \mathrm{L}^{-1}\right]$ & 0.017 & 0.003 & 0.001 & 0.006 & 0.006 & 0.009 \\
\hline $\mathrm{NO}_{3}^{-}\left[\mathrm{mg} \mathrm{N} \mathrm{L}^{-1}\right]$ & 0.04 & 0.41 & 0.86 & 0.33 & 0.33 & 0.50 \\
\hline total $\mathrm{Fe}\left[\mathrm{mg} \mathrm{L}^{-1}\right]$ & 3.00 & 0.13 & 0.01 & 2.25 & 2.07 & 0.01 \\
\hline $\mathrm{Mn}\left[\mathrm{mg} \mathrm{L}^{-1}\right]$ & 0.12 & 0.02 & 0.01 & 0.09 & 0.09 & 0.01 \\
\hline $\mathrm{H}_{2} \mathrm{~S}\left[\mathrm{mg} \mathrm{L}^{-1}\right]$ & 0.02 & n.m. & $<0.02$ & $<0.02$ & $<0.02$ & $<0.02$ \\
\hline $\mathrm{CH}_{4}\left[\mathrm{mg} \mathrm{L}^{-1}\right]$ & 0.07 & n.m. & $<0.01$ & 0.01 & $<0.01$ & $<0.01$ \\
\hline $\mathrm{P}\left[\mathrm{mg} \mathrm{L}^{-1}\right]$ & 0.274 & 0.027 & 0.022 & 0.020 & 0.018 & $<0.01$ \\
\hline Alkalinity [as $\mathrm{mg} \mathrm{HCO}_{3}^{-} \mathrm{L}^{-1}$ ] & 363 & 364 & 357 & 358 & 348 & 342 \\
\hline $\mathrm{Ca}\left[\mathrm{mg} \mathrm{L}^{-1}\right]$ & 85 & n.m. & 83 & 113 & n.m. & 106 \\
\hline $\mathrm{Cl}^{-}\left[\mathrm{mg} \mathrm{L}^{-1}\right]$ & 56 & n.m. & 51 & 69 & n.m. & 66 \\
\hline $\mathrm{SO}_{4}^{2-}\left[\mathrm{mg} \mathrm{L}^{-1}\right]$ & 8 & n.m. & 9 & 49 & n.m. & 44 \\
\hline $\mathrm{NVOC}\left[\mathrm{mg} \mathrm{L}^{-1}\right]$ & 2.6 & n.m. & 2.5 & 2.1 & n.m. & 1.7 \\
\hline
\end{tabular}

n.m.: not measured

Two lab-scale columns were packed with sand from $30 \mathrm{~cm}$ depth of the secondary filter $(0.8-1.4 \mathrm{~mm}$ quartz $)$ and filter effluent water was used as influent substrate, enriched with ammonium (stock solution was prepared

102 from $\mathrm{NH}_{4} \mathrm{Cl}$; analytical grade). In one of the columns, extra trace metals were added. Trace metals stock solution (adapted from Verhagen and Laanbroek, 1991) was prepared from $\mathrm{NiCl}_{2} \cdot 6 \mathrm{H}_{2} \mathrm{O}, \mathrm{CoCl}_{2} \cdot 6 \mathrm{H}_{2} \mathrm{O}, \mathrm{CuCl}_{2} \cdot 2 \mathrm{H}_{2} \mathrm{O}$, 

extra trace metals added to the substrate of the column were: $6 \mu \mathrm{g} \mathrm{Ni} \mathrm{L}{ }^{-1}, 6 \mu \mathrm{g} \mathrm{Co} \mathrm{L} \mathrm{L}^{-1}, 6 \mu \mathrm{g} \mathrm{Cu} \mathrm{L}{ }^{-1}, 33 \mu \mathrm{g} \mathrm{Zn} \mathrm{L}{ }^{-1}$, $10 \mu \mathrm{g} \mathrm{Mo} \mathrm{L}^{-1}, 18 \mu \mathrm{g} \mathrm{W} \mathrm{L} \mathrm{L}^{-1}$, and $11 \mu \mathrm{g} \mathrm{B} \mathrm{L}^{-1}$. The other column was a control without addition of metals.

107 The lab-scale columns were first operated for $54 \mathrm{~h}$ at the volumetric ammonium loading rate (ALR) of the fullscale system of $2.0 \mathrm{~g} \mathrm{NH}_{4}-\mathrm{N} \mathrm{m}^{-3}$ filter material $\mathrm{h}^{-1}$. When ammonium concentrations in the effluent of the

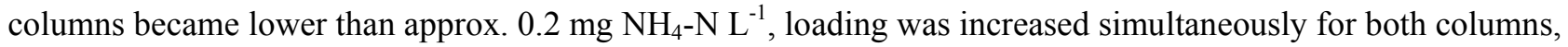
to avoid primary substrate limitations. After $54 \mathrm{~h}$ of operation, ALR was increased to $5.4 \mathrm{~g} \mathrm{NH}_{4}-\mathrm{N} \mathrm{m}^{-3} \mathrm{~h}^{-1}$, and after $236 \mathrm{~h}$, furthermore increased to $8.0 \mathrm{~g} \mathrm{NH}_{4}-\mathrm{N} \mathrm{m}^{-3} \mathrm{~h}^{-1}$, until the experiment was stopped after $289 \mathrm{~h}$. Ammonium influent concentrations were $1.2 \mathrm{mg} \mathrm{NH}_{4}-\mathrm{N} \mathrm{L}^{-1}$ for the lowest ALR and $2.1 \mathrm{mg} \mathrm{NH}_{4}-\mathrm{N} \mathrm{L}^{-1}$ for the two higher ALRs. Effluent water was sampled and ammonium concentrations were analyzed. The effect of trace metals addition was quantified by comparing the volumetric ammonium removal rates (ARRs) of both columns, at the different ALRs. ALRs and ARRs for the lab-scale study were calculated as described in Tatari et al. (2013), and have the units $\left[\mathrm{g} \mathrm{NH}_{4}-\mathrm{N} \mathrm{m}^{-3} \mathrm{~h}^{-1}\right.$, where $\mathrm{m}^{-3}$ refers to the volume of filter material in the column. During the experiment, effluent $\mathrm{pH}$, concentration of dissolved oxygen and temperature were monitored.

Subsequent to the lab-scale study, we carried out a full-scale investigation. Here only copper was dosed as trace metal, because of its specific importance for nitrification (Ensign et al., 1993; Sayavedra-Soto and Arp, 2011). The study lasted for 280 days and was conducted at Nærum GWTP, Denmark

\subsubsection{Characteristics of the groundwater treatment plant} Nærum GWTP treats anoxic groundwater, abstracted from a limestone aquifer, also relatively high in alkalinity

124 (Table 1), with stairs aeration prior to six identical single-stage biological rapid sand filters in parallel. Filters are 125 identical in terms of filter material, backwash procedure, and construction and therefore hydraulic and substrate loading rates. Since de-ironing primary filtration is not used, the iron load to the biological filters at Nærum is 
considerably higher than to the secondary filters at Langerød (Table 1). The plant runs intermittently for approx. $12 \mathrm{~h}$ per day, with operating intervals of approx. $4 \mathrm{~h}$, interrupted by $4 \mathrm{~h}$ breaks. During operation, total treatment flow is $190 \mathrm{~m}^{3} \mathrm{~h}^{-1}$, resulting in around $32 \mathrm{~m}^{3} \mathrm{~h}^{-1}$ per filter. Dividing the volumetric flow rate per filter $\left(32 \mathrm{~m}^{3} \mathrm{~h}^{-1}\right)$ by the cross-sectional area of a filter $\left(19.2 \mathrm{~m}^{2}\right)$, the hydraulic loading rate is calculated to be $1.7 \mathrm{~m} \mathrm{~h}^{-1}$. The active layer (0.8-1.4 mm quartz; assumed active for removal of contaminants) of the filters is $0.6 \mathrm{~m}$ deep, and is followed by 5 layers of support material of different grain sizes, resulting in a total depth of $1.15 \mathrm{~m}$. After treatment of 2,500 $\mathrm{m}^{3}$ of water per filter, filters are backwashed with a 6 minute air scour, followed by a water backwash at a rate of $30 \mathrm{~m} \mathrm{~h}^{-1}$ for 4.5 minutes. Ever since the filter material and piping were replaced in 2012, the GWTP has not been able to completely remove influent ammonium, having average effluent concentrations of around $0.17 \pm 0.05 \mathrm{mg} \mathrm{NH}_{4}-\mathrm{N} \mathrm{L}^{-1}(\mathrm{n}=8$, sampled in between July 2012 and March 2014).

\subsubsection{Experimental design}

Experiments were conducted with two full-scale filters. The first experiment (at Filter 4) aimed at determining how copper dosing affects nitrification over time and over filter depth. Copper was added to the filter for 117 days, employing electrolysis with a rod-shaped copper electrode of $4 \mathrm{~mm}$ diameter. The electrode was installed in the box-shaped inlet structure of the filter. During filter operation, water passed the electrolysis system in the inlet structure, resulting in a continuous release and concentrations of $0.050-1 \mu \mathrm{g} \mathrm{Cu} \mathrm{L}{ }^{-1}$. During non-operation continuously during filter operation and as a pulse spike in the beginning of each operation interval. The decrease in length of the copper electrode was regularly measured, to determine the amount of copper released during the 117 day dosing period. Influent and effluent water from Filter 4 was analyzed on site for ammonium with an ammonium auto-analyzer (Hach Lange, AMTAX $^{\mathrm{TM}} \mathrm{sc}$ ) at a frequency of $30 \mathrm{~min}$, in order to capture the effect of copper dosing on ammonium removal. Water over depth of Filter 4 was sampled before copper dosing 
151 (day 0 ), and subsequently after $7,12,23,37,57,85$, and 117 days with copper dosing, as well as 116 days after 152 copper dosing was stopped.

153 A second experiment (at Filter 5) investigated the persistence of the effect of copper dosing on nitrification over 154 filter depth after dosing was stopped. Copper was added to the filter for 42 days, employing the same method as previously described for Filter 4. Water samples over depth of the filter were collected before copper dosing (day 0), and after 14 and 42 days with copper dosing. On day 42, the electrode was removed, and further water depth sampling was conducted at 14, 84, and 238 days after copper dosing was stopped. Furthermore, 11 influent and effluent water samples were taken during the dosing. After dosing was stopped, water was sampled every 2-3 weeks for 238 days, resulting in 14 additional measurements, besides the depth samples.

For both experiments, the effect of copper dosing on nitrification was evaluated by comparing ammonium removal performance before dosing to performance with dosing. The ammonium loading rate to the filters at the plant was stable during the whole experimental period $\left(0.50 \pm 0.01 \mathrm{~g} \mathrm{NH}_{4}-\mathrm{N} \mathrm{m}^{-3} \mathrm{~h}^{-1}\right)$; the start and respectively stop of copper dosing were therefore the only interventions made in the experiments, and changes in removal performance could thus be related to these interventions. Effluent ammonium concentrations of a third full-scale filter, which did not receive copper dosing, were additionally monitored as a control. Influent and effluent concentrations of dissolved oxygen, $\mathrm{pH}$ and temperature were monitored during both experiments.

\subsubsection{Water and media sampling}

168 Water over depth of the filters was collected through a PTFE tube, inside a supporting rigid stainless steel sampling probe. The probe was inserted into the filters at an angle of $45^{\circ}$, to depths of $5,10,20,30,40,50,60$, 17075,85 , and $95 \mathrm{~cm}$. Water was extracted with a peristaltic pump (Ole Dich, $101 \mathrm{ACR}$ ) at a rate of $25 \mathrm{~mL} \mathrm{~min}^{-1}$. 171 Influent water was sampled from the top of the filters and effluent water from a sampling tap. Sampling of a full 172 water depth profile was completed within $1 \mathrm{~h}$, during which the sampled filter was under full operation, at 173 constant flow. Water depth samples were always collected at the same time within a filter cycle, one day after 
174 filter backwash. Samples for ammonium and nitrite were immediately filtered through a sterile $0.2 \mu \mathrm{m}$ filter 175 (Sartorius, Minisart ${ }^{\circledR}$ ), stored at $4{ }^{\circ} \mathrm{C}$, and analyzed within $24 \mathrm{~h}$; or frozen at $-20{ }^{\circ} \mathrm{C}$ and analyzed within 2 weeks. Influent and effluent samples for total copper were collected unfiltered and immediately acidified with 65 $\%$ nitric acid (Merck, Suprapur $\left.{ }^{\circledR}\right)$ to $\mathrm{pH}<2$, and stored at $4{ }^{\circ} \mathrm{C}$ until analysis. Samples for dissolved copper were filtered through a $0.2 \mu \mathrm{m}$ filter before acidifying.

179 Core samples of filter media from 0 to $40 \mathrm{~cm}$ filter depth were collected from Filter 4 using an acrylic glass tube 180 (Length: $60 \mathrm{~cm}$, internal diameter: $5.2 \mathrm{~cm}$ ), close to where water samples over filter depth were taken. The filter 181 was backwashed just before sampling, and samples were collected one day before copper dosing started (day -1), after 22 and 116 days with copper dosing, as well as 115 days after dosing was stopped. Cores were subdivided into four $10-\mathrm{cm}$ sections and sub-samples were transported to the laboratory for homogenization and further 184 analysis of the metal content on the sand. Knowing the copper content on sand [ $\mathrm{mg} \mathrm{Cu} \mathrm{kg}^{-1}$ wet sand] and the sand wet bulk density of $1,733 \mathrm{~kg} \mathrm{~m}^{-3}$, the total amount of copper in the top $40 \mathrm{~cm}$ of the filter was calculated for the respective sampling days.

\subsubsection{Calculation of ammonium loading and removal rates}

188 The volumetric Ammonium Loading Rate of the full-scale system at Nærum GWTP was calculated as ALR = $189 \mathrm{Qc}_{\mathrm{in}} / \mathrm{A} \Delta \mathrm{z}$, where $\mathrm{Q}$ is the filter flow rate, $\mathrm{c}_{\mathrm{in}}$ is the influent concentration of ammonium, $\mathrm{A}$ is the filter cross 190 section area, and $\Delta \mathrm{z}$ is the full filter depth $(115 \mathrm{~cm})$. The volumetric Ammonium Removal Rate was defined as $191 \mathrm{ARR}=\mathrm{Q}\left(\mathrm{c}_{\mathrm{in}}-\mathrm{c}_{\mathrm{out}}\right) / \mathrm{A} \Delta \mathrm{z}$, where $\mathrm{c}_{\text {out }}$ is the filter effluent concentration of ammonium. When referring to an $\mathrm{ARR}$ 192 of a specific layer of the filter, $\mathrm{c}_{\mathrm{in}}$ and $\mathrm{c}_{\mathrm{out}}$ are the ammonium influent and effluent concentrations to and from 193 this layer. $\Delta \mathrm{z}$ is the depth of that specific layer (e.g.: for calculating the ARR of the support material $(60-115 \mathrm{~cm}$ 194 depth), $c_{\text {in }}$ and $\mathrm{c}_{\text {out }}$ are the ammonium concentrations at 60 and $115 \mathrm{~cm}$ depth, respectively, and $\Delta \mathrm{z}$ is $0.55 \mathrm{~m}$ ). 195 The unit of the ALR and the ARR is $\left[\mathrm{g} \mathrm{NH}_{4}-\mathrm{N} \mathrm{m}^{-3} \mathrm{~h}^{-1}\right.$ ], where $\mathrm{m}^{-3}$ refers to volume of filter material. 
Ammonium and nitrite were determined with colorimetric methods according to APHA 4500-NH3-F and APHA 4500-NO2-B (APHA, AWWA, WEF, 2005) with quantification limits of 0.01 and $0.002 \mathrm{mg} \mathrm{N} \mathrm{L}^{-1}$, respectively.

200 For the ammonium auto-analyzer monitoring influent and effluent ammonium concentrations of full-scale Filter

2014 , the quantification limit was $0.02 \mathrm{mg} \mathrm{NH}_{4}-\mathrm{N} \mathrm{L}^{-1}$.

202 To determine the content of metals on the filter material, sub-samples were digested in triplicates using

203 microwave assisted acid digestion (Anton Paar; Multiwave 3000 SOLV - Microwave Reaction System) with

$204 \mathrm{HNO}_{3}$ and $\mathrm{HCl}$, analogous to EPA method 3051A (USEPA, 2007a). Copper in water samples and the digest was 205 determined by inductively coupled plasma mass spectrometry (Agilent Technologies, 7700 Series ICP-MS), 206 analogous to EPA method 6020A (USEPA, 2007b), with a quantification limit of $0.050 \mu \mathrm{g} \mathrm{Cu} \mathrm{L^{-1 }}$.

207 Dissolved oxygen and $\mathrm{pH}$ during all experiments were measured with a hand held meter (WTW, Multi 3430, 208 with $\mathrm{FDO}^{\circledR} 925$ and SenTix ${ }^{\circledR} 940$ probes). Total alkalinity (as $\mathrm{HCO}_{3}^{-}$) was determined by the titrimetric method 209 according to APHA 2320 (APHA, AWWA, WEF, 2005).

$211 \quad 3 . \quad$ Results and Discussion

$212 \quad 3.1 \quad$ Effect of trace metals on ammonium removal in the lab-scale study

213 Volumetric ammonium removal rates (ARRs) of a lab-scale column with trace metal addition were compared to 214 ARRs of a control, at different volumetric ammonium loading rates (ALRs) (Fig. 1). During the experiment, 215 effluent concentration of dissolved oxygen was never lower than $4.5 \mathrm{mg} \mathrm{L}^{-1}$ and influent water to the columns 216 was well-buffered, with an average total alkalinity concentration of 6.1 meq $\mathrm{HCO}_{3}{ }^{-} \mathrm{L}^{-1}$. The average $\mathrm{pH}$ was 217 7.84. Nitrification limitation by the above factors was therefore excluded. The average temperature during the 218 lab-experiments was $7.2 \pm 1.4^{\circ} \mathrm{C}$. 

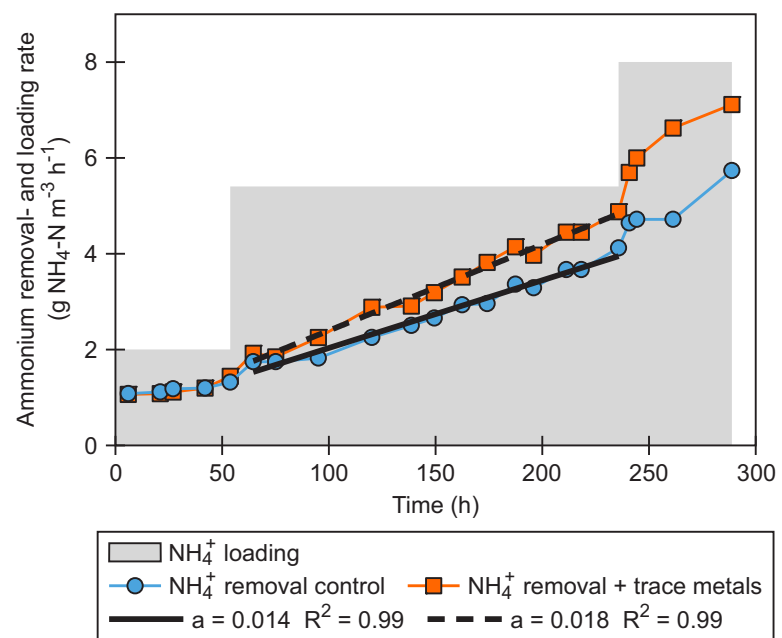

Figure 1: Lab-scale study with trace metals. Volumetric ammonium removal rate (ARR) for the control column and for the column with additional trace metals, for the three different volumetric ammonium loading rates (ALR) applied (shaded area). The depicted lines show linear regression fits to the removal rate data when columns were operated at a loading rate of $5.4 \mathrm{~g} \mathrm{NH}_{4}-\mathrm{N} \mathrm{m}^{-3} \mathrm{~h}^{-1}$. “a”: slope of regressions,

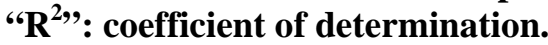

At an ALR of $2.0 \mathrm{~g} \mathrm{NH}_{4}-\mathrm{N} \mathrm{m}^{-3} \mathrm{~h}^{-1}$ during the first $54 \mathrm{~h}$ of the experiment, ARR in the column with added trace metals was on average $1.1 \mathrm{~g} \mathrm{NH}_{4}-\mathrm{N} \mathrm{m}^{-3} \mathrm{~h}^{-1}$, and therefore not substantially different $(<10 \%)$ from the control. When the ALR was increased to $5.4 \mathrm{~g} \mathrm{NH}_{4}-\mathrm{N} \mathrm{m}^{-3} \mathrm{~h}^{-1}$ (between 65 and $236 \mathrm{~h}$ ), the ARR was on average $17 \%$ higher for the column with added trace metals. Linear regressions for this period $\left(n=13, R^{2}=0.99\right)$ showed that the ARR of the control increased with $0.014 \mathrm{~g} \mathrm{NH}_{4}-\mathrm{N} \mathrm{m}^{-3} \mathrm{~h}^{-1}$, per hour. In contrast, the change over time for the column with added trace metals was $0.018 \mathrm{~g} \mathrm{NH}_{4}-\mathrm{N} \mathrm{m}^{-3} \mathrm{~h}^{-1}$ per hour (Fig. 1), i.e. the ARR increased faster under trace metal addition. At $236 \mathrm{~h}$, the ARR of the column with trace metals was $4.9 \mathrm{~g} \mathrm{NH}_{4}-\mathrm{N} \mathrm{m}^{-3} \mathrm{~h}^{-1}$ and therefore $20 \%$ higher than $4.1 \mathrm{~g} \mathrm{NH}_{4}-\mathrm{N} \mathrm{m}^{-3} \mathrm{~h}^{-1}$ in the control. During the ALR phase of $8.0 \mathrm{~g} \mathrm{NH}_{4}-\mathrm{N} \mathrm{m}^{-3} \mathrm{~h}^{-1}$, ARR was on average $22 \%$ higher for the column with added trace metals, compared to the control. Nitrogen balances showed that oxidized ammonium was present as nitrite and/or nitrate (data not shown).

The experiment demonstrated that a trace metal mixture, including copper, stimulated ammonium removal in a lab-scale column, which was packed with sand from a full-scale biological filter. Influent concentration of 
238 copper in the column with added trace metals was $5.9 \mu \mathrm{g} \mathrm{Cu} \mathrm{L}^{-1}$, which was on the lower end of $5-100 \mu \mathrm{g} \mathrm{Cu} \mathrm{L}$

239 , reported to stimulate activity of Nitrosomonas europaea in pure culture (Zhang et al., 2009, and references 240 therein). An even higher concentration of $6,350 \mu \mathrm{g} \mathrm{Cu} \mathrm{L}^{-1}$ was needed to stimulate the activity of the enzyme 241 ammonia monooxygenase in vitro (Ensign et al., 1993). On the other hand, metals such as $\mathrm{Ni}^{2+}, \mathrm{Co}^{2+}$, and $\mathrm{Zn}^{2+}$, 242 tested at a concentration range of 1 and $5000 \mu \mathrm{M}$, were not able to stimulate ammonium oxidation activity 243 (Ensign et al., 1993). Inherently due to the different type of study (in vitro, with cell extracts), copper 244 concentrations can hardly be compared to our study. However, due to the specific requirement of copper for 245 nitrification (Ensign et al., 1993; Sayavedra-Soto and Arp, 2011), and because copper concentrations in the raw 246 water of the GWTP of the following full-scale study were extremely low $\left(<0.050 \mu \mathrm{g} \mathrm{L}^{-1}\right)$, the subsequent 247 investigation focused on controlled dosing of copper only.

\section{$248 \quad 3.2 \quad$ Response of ammonium removal in full-scale to copper dosing}

249 Influent and effluent ammonium concentrations of Filter 4 at Nærum GWTP were monitored at high frequency 250 with an auto-analyzer to study the full-scale filter's response to the dosing of copper. The GWTP was initially 251 designed for a volumetric ammonium loading rate (ALR) to the filters of $1.5 \mathrm{~g} \mathrm{NH}_{4}-\mathrm{N} \mathrm{m}^{-3} \mathrm{~h}^{-1}$, but was actually 252 operated under a much lower ALR of $0.5 \mathrm{~g} \mathrm{NH}_{4}-\mathrm{N} \mathrm{m}^{-3} \mathrm{~h}^{-1}$. Yet, the filters were not able to remove the decreased 253 loading. Before dosing of copper, filter effluent ammonium concentrations were stable at approx. $0.18 \mathrm{mg} \mathrm{NH}_{4^{-}}$ $254 \mathrm{~N} \mathrm{~L}^{-1}$ (Fig. 2), equivalent to a volumetric ammonium removal rate (ARR) of $0.22 \mathrm{~g} \mathrm{NH}_{4}-\mathrm{N} \mathrm{m}^{-3} \mathrm{~h}^{-1}$, and a removal 255 efficiency of only $44 \%$ of the applied load. Copper influent concentration to the filter was $<0.050 \mu \mathrm{g}$ total $\mathrm{Cu} \mathrm{L}^{-}$ $256{ }^{1}$ (Table 2). 
Table 2: Copper concentrations in filter influent and effluent in relation to copper dosing, for Filter 4 and reported for selected samples in ( ).

\begin{tabular}{llc}
\hline \multirow{2}{*}{ Day } & \multicolumn{2}{c}{ Cu concentration $\left[\mu \mathrm{L}^{-1}\right]$} \\
& Influent & Effluent \\
\hline
\end{tabular}

\begin{tabular}{cccc} 
& & Influent & Effluent \\
\hline & & Filter $\mathbf{4}$ & \\
\hline Before & -62 & $<0.050$ & n.m. \\
$\mathrm{Cu}$ & -20 & $<0.050$ & n.m. \\
dosing & -6 & $<0.050$ & n.m. \\
& 0 & $<0.050$ & $<0.050$ \\
\hline & 1 & $0.120(0.098)$ & $<0.050(<0.050)$ \\
& 5 & 0.310 & 0.139 \\
\hline During & 12 & $<0.050$ & 0.108 \\
dosing & 19 & $0.591(0.193)$ & $0.126(0.161)$ \\
& 23 & 0.610 & 0.431 \\
& 37 & 0.400 & 0.383 \\
& 57 & 0.245 & 0.289 \\
\hline $\begin{array}{c}\text { After } \\
\text { dosing }\end{array}$ & 11 & 0.482 & 0.196 \\
\hline & 121 & $<0.050$ & 0.089 \\
\hline & 232 & $<0.050$ & $<0.050$ \\
\hline
\end{tabular}

Filter 5

\begin{tabular}{cccc}
\hline & -106 & $<0.050$ & n.m. \\
Before & -58 & $<0.050$ & n.m. \\
$\mathrm{Cu}$ & -16 & $<0.050$ & n.m. \\
dosing & -2 & $<0.050$ & n.m. \\
& 0 & $<0.050$ & $<0.050$ \\
\hline & 1 & 0.157 & n.m. \\
During & 4 & $0.968(0.431)$ & $0.158(0.083)$ \\
$\mathrm{Cu}$ & 7 & 0.077 & 0.078 \\
dosing & 14 & 0.176 & 0.124 \\
& 39 & 0.303 & $<0.050$ \\
\hline & 42 & 0.093 & 0.201 \\
\hline $\begin{array}{c}\mathrm{After} \\
\text { dosing }\end{array}$ & 42 & $<0.050$ & 0.062 \\
\hline & 56 & $<0.050$ & $0.980(0.162)$ \\
\hline
\end{tabular}

n.m.: not measured 
Shortly after the onset of copper dosing, ammonium removal in the filter responded (Fig. 2). Within the first day after the start of dosing, effluent ammonium concentrations started to decrease; latterly during 20 days with copper dosing, effluent concentrations dropped to approx. $0.02 \mathrm{mg} \mathrm{NH}_{4}-\mathrm{N} \mathrm{L}^{-1}$. With an average influent concentration of $0.341 \mathrm{mg} \mathrm{NH}_{4}-\mathrm{N} \mathrm{L}^{-1}$, the ARR for full filter depth was $0.46 \mathrm{~g} \mathrm{NH}_{4}-\mathrm{N} \mathrm{m}^{-3} \mathrm{~h}^{-1}$, more than twice as high as the ARR of approx. $0.22 \mathrm{~g} \mathrm{NH}_{4}-\mathrm{N} \mathrm{m}^{-3} \mathrm{~h}^{-1}$ before copper dosing. After 23 days of dosing, effluent concentrations of Filter 4 were below quantification limit $\left(<0.02 \mathrm{mg} \mathrm{NH}_{4}-\mathrm{N} \mathrm{L}^{-1}\right)$ and remained at this level while copper was dosed during 117 days (Fig. 2). While ammonium removal of Filter 4 increased, the control filter, which did not receive copper dosing, showed no change in removal performance. 20 days after dosing started, the ARR of the control filter was only $0.23 \mathrm{~g} \mathrm{NH}_{4}-\mathrm{N} \mathrm{m}^{-3} \mathrm{~h}^{-1}$, which was comparable to the removal performance of Filter 4 before dosing. Average alkalinity and effluent dissolved oxygen during the experiment were $5.6 \pm 0.1 \mathrm{meq} \mathrm{L}^{-1}$ and $8.3 \pm 0.23 \mathrm{mg} \mathrm{L}^{-1}$. The average $\mathrm{pH}$ was $7.6 \pm 0.2$, and copper dosing did not change the $\mathrm{pH}$ during the experiment.

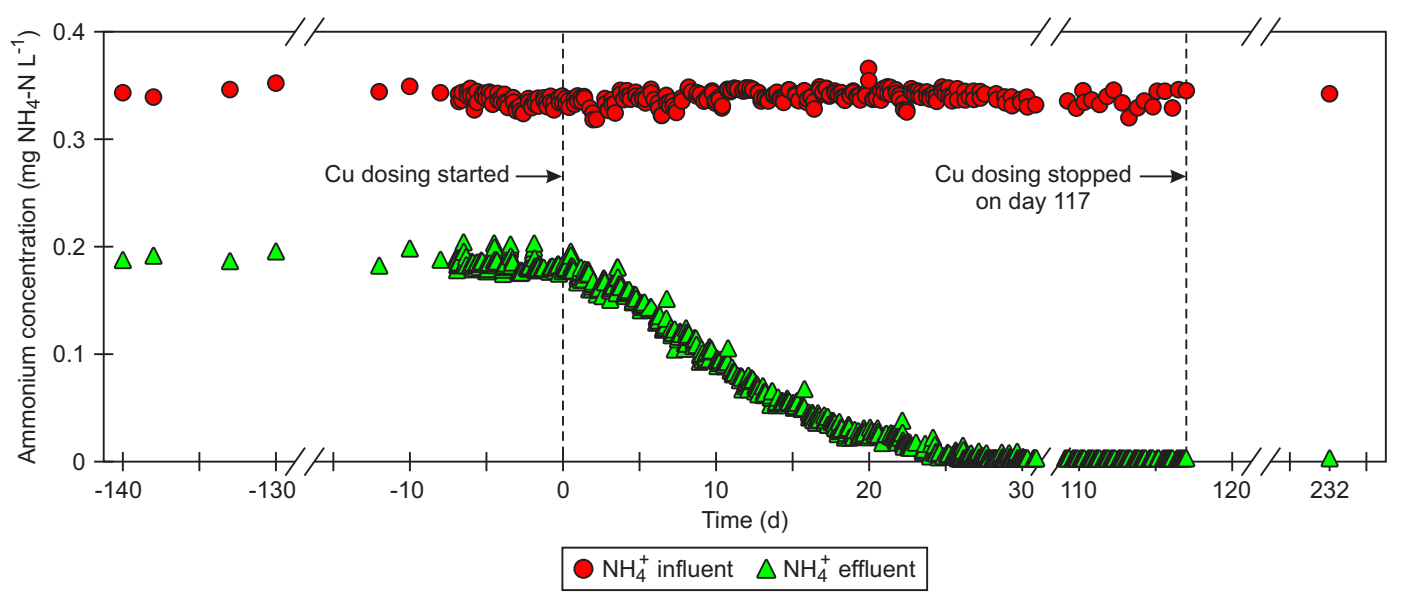

Figure 2: Ammonium influent and effluent concentrations of full-scale Filter 4. Filter effluent concentration of ammonium was stable before copper dosing started on day 0. Dosing lasted for 117 days. All data shown is from samples collected while filter was under operation at constant flow.

The mass of copper dosed to Filter 4 during the first 22 days corresponds to an average dosing concentration of $0.4 \mu \mathrm{g}$ total $\mathrm{Cu} \mathrm{L}^{-1}$, calculated from $4.6 \pm 0.2 \mathrm{~g}$ of copper released into the filter and a total volume of $11,917 \mathrm{~m}^{3}$ 
treated by the filter during that period. From day 23 until 117 when dosing was stopped, an additional $17.4 \pm 0.2$

$299 \mathrm{~g}$ of copper were released, totaling to $22.0 \pm 0.3 \mathrm{~g}$ of copper released during the dosing period. During the 300 continuous dosing phases the influent water had $<1 \mu \mathrm{g}$ total $\mathrm{Cu} \mathrm{L}^{-1}$ (Table 2), which was lower than the $5-30$ $301 \mu \mathrm{g} \mathrm{Cu} \mathrm{L}{ }^{-1}$ needed to stimulate Nitrosomonas europaea in pure culture (Loveless and Painter, 1968). However, 302 this pure culture study, with an isolate from an activated sludge system, and a culture medium containing EDTA 303 as chelating agent, is not comparable to our drinking water system with low ammonium concentrations. A rapid 304 stimulation of nitrification in biological filters due to copper dosing, as observed in our experiment, has not 305 previously been reported.

306 Filter influent concentrations of copper without dosing were low (Table 2) due to raw water copper 307 concentrations at the GWTP of $<0.050 \mu \mathrm{g}$ total $\mathrm{Cu} \mathrm{L}^{-1}(\mathrm{n}=4$, sampled between 62 days before and 5 days with 308 copper dosing). Processes such as sorption and complexation during treatment in the filter may even further 309 decrease copper availability for nitrification. It should be noted that insufficiently low copper concentrations 310 may not be limited to groundwater, but may also be a problem in surface water, since available water phase 311 concentrations can be low in lake- and river water, where copper can be bound in organic complexes (Xue et al., 312 1996) or in bottom sediments (Sanchez and Lee, 1973). Our findings showed that copper dosing can successfully 313 remove nitrification limitations due to copper deficiency during groundwater treatment, and we suggest that 314 nitrification limitation by lack of copper should be considered also at water treatment plants treating surface 315 water, when ammonium removal is incomplete.

\section{$316 \quad 3.3 \quad$ Effect of copper dosing on ammonium and nitrite removal over full-scale depth}

317 Water sampling over depth of Filter 4 additionally revealed the effect of copper on ammonium profiles over 318 filter depth. Before copper dosing, the ammonium concentration decreased slowly over the full depth of Filter 4 319 (Fig. 3A), from 0.352 to $0.280 \mathrm{mg} \mathrm{NH}_{4}-\mathrm{N} \mathrm{L}^{-1}$ in the top $60 \mathrm{~cm}$, and further down to $0.180 \mathrm{mg} \mathrm{NH}_{4}-\mathrm{N} \mathrm{L}^{-1}$ in the 320 effluent of the filter. This observation was surprising, since the deeper section from 60 to $115 \mathrm{~cm}$ is the support 
material of the filter (Fig. 3C), which is not designed to remove ammonium. Yet it shows that a filter's support layers can also be active for biological removal, and not only act as bearing layers for the active layers. Contrary to previous reports (Lee et al., 2014), removal in this filter was not stratified with most activity in the top part. The higher ammonium removal in the deeper parts of the filter (especially from $85-115 \mathrm{~cm}$; Fig. 3A) increased the concentration of nitrite, due to too short contact time for further oxidation to nitrate, leading to a nitrite concentration of $0.009 \mathrm{mg} \mathrm{NO}_{2}-\mathrm{N} \mathrm{L}^{-1}$ in the effluent (Fig. 3B). Consequently, the filter failed to meet both quality standards, for ammonium and for nitrite.

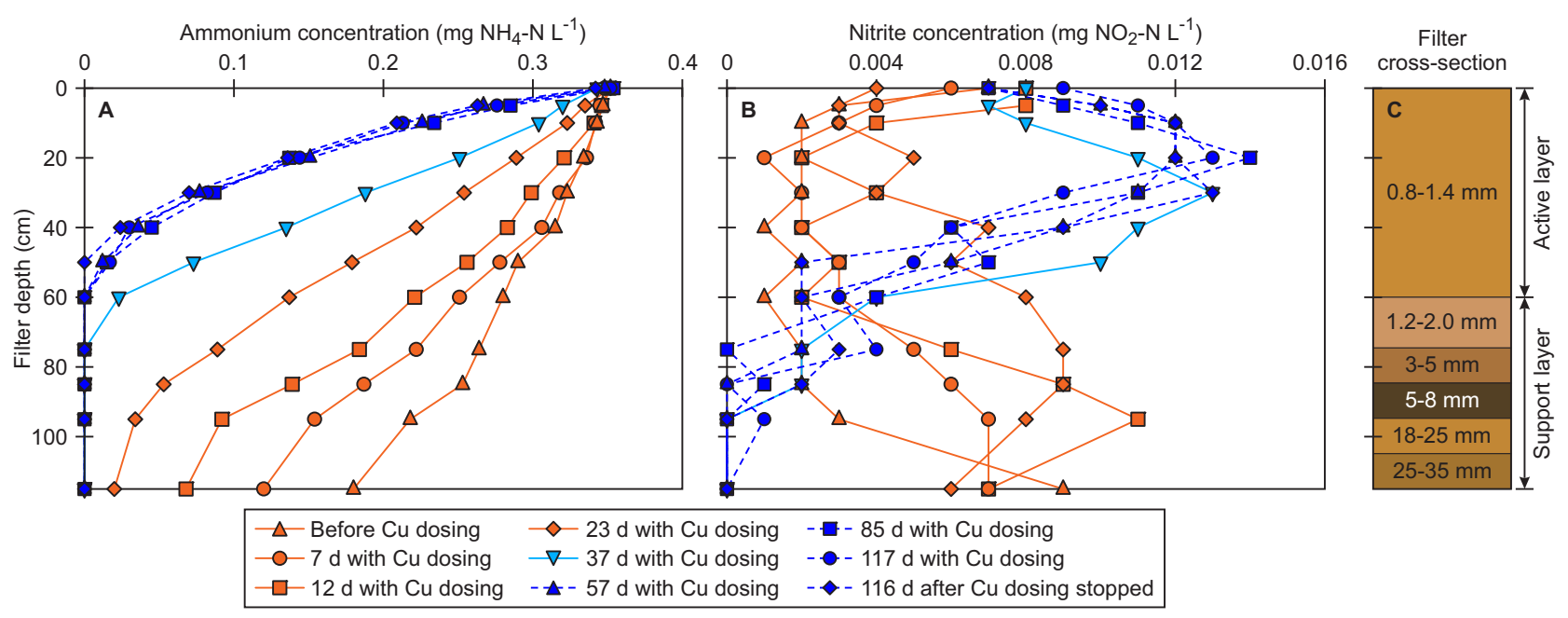

Figure 3: Ammonium (A) and nitrite (B) concentrations over depth of Filter 4, over time in relation to copper dosing. $C$ illustrates a cross-section of the filter, with the active layer from 0-60 cm depth, and the support layer from $60-115 \mathrm{~cm}$ depth.

Right after the onset of copper dosing, ammonium removal was mainly stimulated in the deeper layer of the filter ( $7 \& 12 \mathrm{~d}$ with $\mathrm{Cu}$ dosing, Fig. 3A), where removal activity prior to dosing was highest. Within 12 days, $0.116 \mathrm{mg} \mathrm{NH}_{4}-\mathrm{N} \mathrm{L}^{-1}$ were removed from 75-115 cm depth, compared to $0.084 \mathrm{mg} \mathrm{NH}_{4}-\mathrm{N} \mathrm{L}^{-1}$ before dosing. With dosing, copper fully penetrated the filter, as demonstrated by an average copper effluent concentration of $0.15 \mu \mathrm{g} \mathrm{Cu} \mathrm{L}^{-1}(\mathrm{n}=7$ ) (Table 2) during the first 23 days. Copper dosing moved ammonium removal further upwards in the filter, until a steady state, stratified removal was reached between 37 and 57 days with copper 
dosing. All ammonium was then removed in the active layer $(0-60 \mathrm{~cm})$ of the filter (Fig. 3A \& C). The same

340 effect of copper was later observed in the second experiment with Filter 5, described in detail in section 3.5.

341 Ammonium removal profiles over depth of Filter 4 remained unchanged during continued dosing of copper for 34260 more days (117 d with $\mathrm{Cu}$ dosing, Fig. 3A). Peaks in nitrite concentrations were observed below sections in 343 the filter where ammonium oxidation was highest (Fig. 3A \& B); with breakthrough of nitrite until ammonium 344 was removed in the active layer of the filter. Shifting the ammonium removal from the deeper layers to the active 345 layer with copper dosing also resulted in sufficient contact time for nitrite oxidation. It may furthermore be a 346 possibility that copper had stimulated the nitrite oxidizing bacteria itself, as copper is contained in the enzyme 347 nitrite oxidoreductase (Meincke et al., 1992), essential to nitrite oxidizers. A mass balance showed that oxidized 348 ammonium was present as nitrate and/or nitrite (data not shown), meaning that ammonium removal processes 349 other than nitrification were negligible. Considering influent and effluent ammonium concentrations only, the 350 system was at steady-state after 23 days (Fig. 2). Water sampling over depth, however, revealed that after 23 351 days the ammonium removal pattern still changed over filter depth (Fig. 3A).

\subsection{Increase in ammonium removal capacity with copper dosing}

353 To quantify the effect of copper on the filter's ammonium removal capacity, the ARR for specific layers of the 354 filter was calculated from the ammonium profiles over filter depth. Before copper dosing, the ARR of the 355 support material $(60-115 \mathrm{~cm})$ was $0.30 \mathrm{~g} \mathrm{NH}_{4}-\mathrm{N} \mathrm{m}^{-3} \mathrm{~h}^{-1}$, slightly higher than the ARR of the active layer $(0-60$ $356 \mathrm{~cm}$ ) of $0.20 \mathrm{~g} \mathrm{NH}_{4}-\mathrm{N} \mathrm{m}^{-3} \mathrm{~h}^{-1}$ (day 0, Fig. 4). The ARR of the active layer increased when copper dosing shifted 357 ammonium removal upwards in the filter. Also, the ARR of the support material increased after the onset of 358 copper dosing. However, it decreased again after approx. 12 days (Fig. 4), because with increasing ammonium 359 removal in the upper layers, ammonium concentrations were decreased when reaching the support material (e.g. $36023 \mathrm{~d}$ with $\mathrm{Cu}$ dosing, Fig. 3A), resulting in a decrease of the actual ARR of the support material. Hence, no 361 ammonium removal occurred in the support material on days 57, 85, and 117 (Fig. 4), when ammonium was 

fold during 57 days with copper dosing, to $0.98 \mathrm{~g} \mathrm{NH}_{4}-\mathrm{N} \mathrm{m}^{-3} \mathrm{~h}^{-1}$ (Fig. 4).

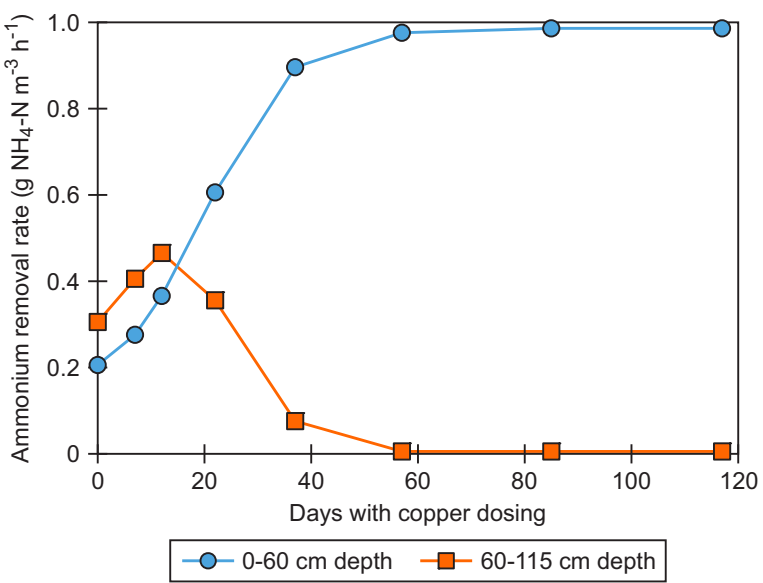

Figure 4: Volumetric ammonium removal rates $(A R R)$ of the active layer $(0-60 \mathrm{~cm})$ and the support layer $(60-115 \mathrm{~cm})$ of Filter 4, over time in relation to copper dosing.

Based on full filter depth $(0-115 \mathrm{~cm})$, the ARR was $0.22 \mathrm{~g} \mathrm{NH}_{4}-\mathrm{N} \mathrm{m}^{-3} \mathrm{~h}^{-1}$ before copper dosing, which was the maximum removal capacity of the filter, given the applied normal operating and loading conditions. Copper dosing increased the ARR to $0.5 \mathrm{~g} \mathrm{NH}_{4}-\mathrm{N} \mathrm{m}^{-3} \mathrm{~h}^{-1}$, and thus increased the ammonium removal capacity. The initial ability of the support material to remove ammonium before all ammonium was oxidized in the active layer, indicated extra ammonium removal capacity in the deeper layers of the filter. However, the maximum

373 removal capacity of the filter with copper dosing was unknown, since the filter was, at that point, limited by 374 ammonium, and the ALR to the full-scale system could not be further increased through increasing either flow or ammonium concentration. Information about the maximum removal capacity of a biological filter is important,

376 since it provides indications about filter performance under dynamic operating conditions, such as varying flow 377 rates or shifting wells and therefore influent water composition (Lee et al., 2014). 
378 Considering the top $10 \mathrm{~cm}$ layer of the filter, the ARR increased almost 14-fold within 57 days of dosing, from

3790.15 to $2.03 \mathrm{~g} \mathrm{NH}_{4}-\mathrm{N} \mathrm{m}^{-3} \mathrm{~h}^{-1}$, revealing a considerable increase in removal capacity of the filter material in this 380 layer. The strong increase in removal rates throughout the active layer allowed for a complete nitrification, 381 including the complete oxidation of nitrite. This increase due to copper dosing therefore enabled the remediation 382 of incomplete nitrification.

384 To investigate the persistence of removal performance, ammonium depth profiles and effluent concentrations were monitored after copper dosing was stopped. A profile over depth of Filter 4, measured 116 days after the copper electrode was removed, demonstrated that copper dosing had a long-term positive effect on ammonium removal. The ammonium removal pattern over depth was unchanged, compared to the profile before dosing was stopped (117 d with $\mathrm{Cu}$ dosing \& $116 \mathrm{~d}$ after $\mathrm{Cu}$ dosing stopped, Fig. 3A).

Whereas dosing to Filter 4 lasted for 117 days, copper was dosed in a second experiment with Filter 5 for only 42 days. Water depth sampling before the onset of dosing denoted an ammonium profile comparable to the one of Filter 4 (Fig. 5 \& Fig. 3A), even though ammonium removal was initially slightly higher in Filter 5. After the onset of copper dosing to Filter 5, nitrification responded promptly, and ammonium effluent concentrations stabilized at $<0.01 \mathrm{mg} \mathrm{NH}_{4}-\mathrm{N} \mathrm{L}^{-1}$ within 22 days. Ammonium removal was also shifted upwards in the filter, as was previously observed in Filter 4; and after 42 days with copper dosing, the ammonium removal pattern approached the steady-state pattern exhibited in the first experiment (Fig. $5 \& 57 \mathrm{~d}$ with $\mathrm{Cu}$ dosing, Fig. 3A). Removal over depth was even marginally improved 14 days after dosing stopped, and, furthermore, maintained 397 at later times, e.g. 84 and 238 days after dosing stopped (Fig. 5). Effluent ammonium concentrations, measured every 2-3 weeks for 238 days after dosing stopped, were $<0.01 \mathrm{mg} \mathrm{NH}_{4}-\mathrm{N} \mathrm{L}^{-1}(\mathrm{n}=14)$. These observations therefore confirm the effect of copper dosing on nitrification and its long-lasting properties, as previously demonstrated for Filter 4. After dosing started, Filter 5 was, as in the case of Filter 4, fully penetrated with 
copper effluent concentrations of $0.11 \mu \mathrm{g} \mathrm{Cu} \mathrm{L}^{-1}(\mathrm{n}=5)$. After dosing was stopped, influent copper concentrations 402 decreased back to $<0.050 \mu \mathrm{g} \mathrm{Cu} \mathrm{L}^{-1}$ (Table 2). Potential explanations for the continued stimulation are discussed below in section 3.6. This second experiment showed a clear long-term effect, even though copper was dosed for a shorter period than in the first experiment. This has highly practical and economic implications, as continuous dosing of copper was not necessary for keeping ammonium removal performance high.

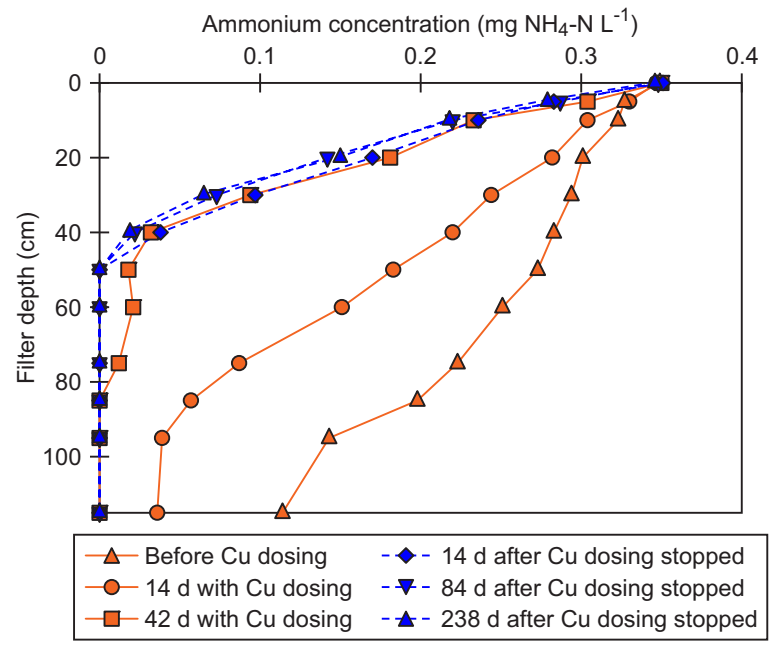

Figure 5: Ammonium concentrations over depth of Filter 5, over time in relation to copper dosing. Copper dosing to this filter lasted for $\mathbf{4 2}$ days.

411 Since copper can readily sorb to iron-oxide (Benjamin et al., 1996) and manganese-oxide coated sand (Han et al., 2006), we investigated the distribution of copper on the top $40 \mathrm{~cm}$ sand of Filter 4, before, during, and after copper dosing. Although influent iron is primarily removed in the top $20 \mathrm{~cm}$ of the filter (Supplementary

414 information, Fig. 1-SI), copper penetrated deeper during dosing and was also accumulated on the filter media 415 below $20 \mathrm{~cm}$ (Fig. 6). Out of the $4.6 \pm 0.2 \mathrm{~g} \mathrm{Cu}$ dosed during the first 22 days, $0.6 \pm 0.2 \mathrm{~g}$ accumulated in the top $41640 \mathrm{~cm}$ of the filter (calculated from the mean of triplicate media analysis \pm standard deviation, and sand wet bulk 417 density). The total amount of copper in this layer was then $2.0 \pm 0.2 \mathrm{~g}$, compared to $1.4 \pm 0.1 \mathrm{~g}$ before dosing 
started. Continued copper dosing increased accumulation further to a total of $3.0 \pm 0.2 \mathrm{~g}$ from 0 to $40 \mathrm{~cm}$ depth

419 of the filter until day 116, when the dosing was stopped and copper content on sand started to decrease again.

420 Nevertheless, the amount on sand 115 days after dosing stopped only decreased to $2.6 \pm 0.1 \mathrm{~g} \mathrm{Cu}$, corresponding

421 to a wash out of $0.4 \pm 0.2 \mathrm{~g}$. This was still approx. $85 \%$ higher than the initial amount, showing that copper was

422 released slower than it accumulated on the media. A release to the water phase was demonstrated through

423 measurements for both filters, as copper was detected in the effluent after dosing of the metal was stopped

424 (Table 2). This may have made copper available in the bulk phase and could possibly explain the sustained

425 nitrification performance (as described in 3.5). Since microbial communities in such filters are organized as a

426 biofilm on the sand (Gülay et al., 2014), copper might furthermore have been (re-)cycled within the biofilm

427 itself, and/or became available to the biofilm after desorption from sand (Simpson, 2008) without actual release

428 to the bulk water phase. In addition, persisting increased ammonium removal might have been caused by

429 biomass growth during copper dosing, with subsequent low (internal and external) decay (Loosdrecht and

430 Henze, 1999).

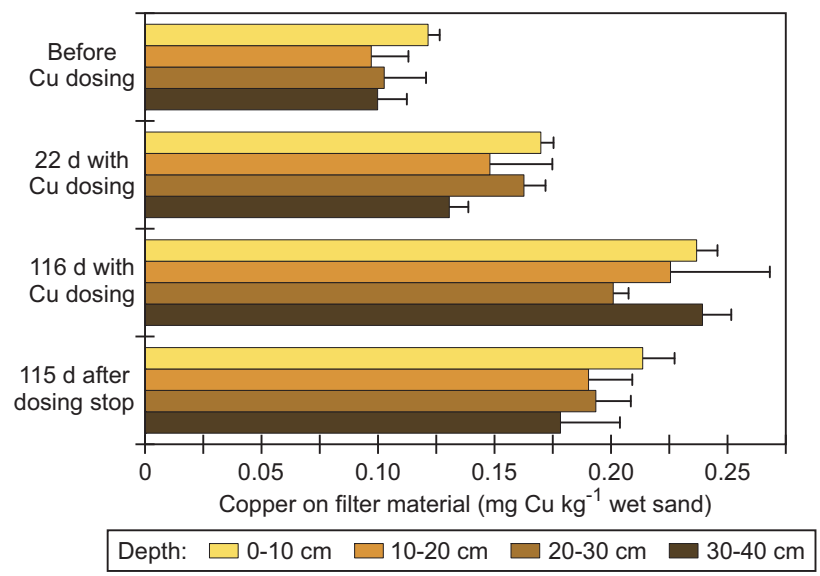

Figure 6: Copper content on sand over depth (0-40 cm) of Filter 4, before copper dosing, 22 and 116 days with dosing, and 115 days after dosing was stopped. All samples were collected right after filter backwash. 
437 A fraction of copper in the water phase was present as dissolved copper (Table 2), which includes free hydrated $438 \mathrm{Cu}^{2+}$ ions and copper complexed with organic and inorganic ligands. The other fraction in the water phase (the 439 difference between total copper and dissolved copper) was sorbed to suspended particles or bound in complexes 440 too large to pass through the $0.2 \mu \mathrm{m}$ pore size filter used for sample filtration. Both sorption and complexation 441 are able to considerably reduce the concentration of free copper (Sylva, 1976) and even though certain 442 microorganisms may be able to use complexed forms of copper, free $\mathrm{Cu}^{2+}$ is generally considered the 443 bioavailable form, controlling growth and activity of nitrifiers (Amin et al., 2013; Jacquot et al., 2014). Since 444 high alkalinity and $\mathrm{pH}$ levels decrease the concentration of free $\mathrm{Cu}^{2+}$ (Zhang and Edwards, 2010), free $\mathrm{Cu}^{2+}$ was 445 likely lower than the measured concentrations of dissolved copper, given the water chemistry as specified in 446 Table 1. Since copper dosing concentrations were low and the highest measured effluent concentrations were $<$ $447 \quad 1.4 \mu \mathrm{g}$ total $\mathrm{Cu} \mathrm{L}^{-1}$ (Table 2), the national guideline for water treatment plants effluent of $100 \mu \mathrm{g}$ total $\mathrm{Cu} \mathrm{L}^{-1}$ was 448 not challenged, and effluent concentrations were several orders of magnitude lower than the health-based 449 guideline of 2,000 $\mu \mathrm{g} \mathrm{Cu} \mathrm{L}^{-1}$ at the consumer's tap (WHO, 2011); these effluent levels remain insignificant 450 compared to release from copper premise plumbing. In any case, nutrient dosing concentrations should be kept 451 as low as possible when used for enhancement of biological treatment, inherent to maintain biological stability in 452 the distribution system.

\section{$454 \quad$ 4. Conclusions}

- Ammonium removal was stimulated in a lab-scale column packed with full-scale filter sand under addition of a trace metal mixture containing copper. Stimulation was more pronounced at increased ammonium loading rates.

- Controlled dosing of copper to a full-scale biological filter decreased ammonium effluent concentrations from a stable level of $0.18 \mathrm{mg} \mathrm{NH}_{4}-\mathrm{N} \mathrm{L}^{-1}$ prior to dosing, to $0.02 \mathrm{mg} \mathrm{NH}_{4}-\mathrm{N} \mathrm{L}^{-1}$ within 20 days. 
474 Overall, our study demonstrated that poor nitrification performance, due to copper deficiency in groundwater 475 based biological rapid sand filters, could be effectively remediated through dosing of copper. Dosing at low 476 concentrations $\left(\sim \mu \mathrm{g} \mathrm{Cu} \mathrm{L}{ }^{-1}\right)$ was a powerful tool for increasing ammonium removal rates and capacity of 477 biological filters, and had a long-term effect on removal performance. We believe that these findings can have a

478 high impact on the water treatment industry.

- $\quad$ Nitrification was stimulated over full filter depth and ammonium and nitrite removal shifted upwards in the filter with copper dosing, leading to stratified removal. The ammonium removal rate of a filter's top $10 \mathrm{~cm}$ increased almost 14 -fold within 57 days of dosing, thereby increasing the filter material's removal capacity.

- The observed stimulation persisted even after copper dosing was stopped. With 42 days of copper dosing to a filter, ammonium removal activity remained high for at least 238 days after dosing was stopped, demonstrating that continuous dosing was not necessary.

- Copper dosing concentrations were low at $<5 \mu \mathrm{g} \mathrm{Cu} \mathrm{L}^{-1}$ and stimulated ammonium removal in full-scale within only 1 day. Copper fully penetrated the filter, with effluent concentrations of up to $1.3 \mu \mathrm{g} \mathrm{Cu} \mathrm{L}{ }^{-1}$, several orders of magnitude below health based drinking water guidelines. Out of $4.6 \pm 0.2 \mathrm{~g} \mathrm{Cu}$ dosed during 22 days, approx. $13 \%$ accumulated on filter media in the top $40 \mathrm{~cm}$.

- After dosing stopped, copper content on filter media in the top $40 \mathrm{~cm}$ decreased slower than it had accumulated during dosing. Effluent copper measurements substantiated a release of copper to the bulk phase, which may possibly explain the observed long-term effect on nitrification.

\section{Acknowledgments}

This work was supported by the Danish Council for Strategic Research via the project DW Biofilters and the Urban Water Tech Research School. The authors gratefully acknowledge help from Jimmi Jørgensen at Nærum 
483 GWTP, Torben Weng at Langerød GWTP, and Charlotte Loewe Jensen from Krüger A/S, and thank Carson O.

484 Lee and Karolina Tatari for their assistance in this project.

References

487 Adriano, D.C., 1986. Trace elements in the terrestrial environment. Springer Verlag Berlin Heidelberg New $488 \quad$ York Tokyo, New York, NY.

489 490 491 492 493 494 495 496

Amin, S.A., Moffett, J.W., Martens-Habbena, W., Jacquot, J.E., Han, Y., Devol, A., Ingalls, A.E., Stahl, D.A., Armbrust, E.V., 2013. Copper requirements of the ammonia-oxidizing archaeon Nitrosopumilus maritimus SCM1 and implications for nitrification in the marine environment. Limnol. Oceanogr. 58, 2037-2045. doi:10.4319/1o.2013.58.6.2037

APHA, AWWA, WEF, 2005. Standard methods for the examination of water and wastewater, 21 st ed. American Public Health Association, Washington, DC.

Arp, D.J., Chain, P.S.G., Klotz, M.G., 2007. The impact of genome analyses on our understanding of ammoniaoxidizing bacteria*. Annu. Rev. Microbiol. 61, 503-528. doi:10.1146/annurev.micro.61.080706.093449

Benjamin, M.M., Sletten, R.S., Bailey, R.P., Bennett, T., 1996. Sorption and filtration of metals using ironoxide-coated sand. Water Res. 30, 2609-2620. doi:10.1016/S0043-1354(96)00161-3

de Vet, W.W.J.M., Kleerebezem, R., van der Wielen, P.W.J.J., Rietveld, L.C., van Loosdrecht, M.C.M., 2011. Assessment of nitrification in groundwater filters for drinking water production by qPCR and activity measurement. Water Res. 45, 4008-4018. doi:10.1016/j.watres.2011.05.005 
de Vet, W.W.J.M., van Loosdrecht, M.C.M., Rietveld, L.C., 2012. Phosphorus limitation in nitrifying groundwater filters. Water Res. 46, 1061-1069. doi:10.1016/j.watres.2011.11.075

Ensign, S.A., Hyman, M.R., Arp, D.J., 1993. In vitro activation of ammonia monooxygenase from Nitrosomonas europaea by copper. J. Bacteriol. 175, 1971-1980.

Gülay, A., Tatari, K., Musovic, S., Mateiu, R. V, Albrechtsen, H.-J., Smets, B.F., 2014. Internal porosity of mineral coating supports microbial activity in rapid sand filters for groundwater treatment. Appl. Environ. Microbiol. 80, 7010-7020. doi:10.1128/AEM.01959-14

Han, R., Zou, W., Zhang, Z., Shi, J., Yang, J., 2006. Removal of copper(II) and lead(II) from aqueous solution by manganese oxide coated sand I. Characterization and kinetic study. J. Hazard. Mater. 137, 384-395. doi:10.1016/j.jhazmat.2006.02.021

Jacquot, J.E., Horak, R.E.A., Amin, S.A., Devol, A.H., Ingalls, A.E., Armbrust, E.V., Stahl, D.A., Moffett, J.W., 2014. Assessment of the potential for copper limitation of ammonia oxidation by Archaea in a dynamic estuary. Mar. Chem. 162, 37-49. doi:10.1016/j.marchem.2014.02.002

Lee, C.O., Boe-Hansen, R., Musovic, S., Smets, B., Albrechtsen, H.-J., Binning, P., 2014. Effects of dynamic operating conditions on nitrification in biological rapid sand filters for drinking water treatment. Water Res. 64, 226-236. doi:10.1016/j.watres.2014.07.001

Leininger, S., Urich, T., Schloter, M., Schwark, L., Qi, J., Nicol, G.W., Prosser, J.I., Schuster, S.C., Schleper, C., 2006. Archaea predominate among ammonia-oxidizing prokaryotes in soils. Nature 442, 806-809. doi:10.1038/nature04983

Loosdrecht, M. Van, Henze, M., 1999. Maintenance, endogeneous respiration, lysis, decay and predation. Water Sci. Technol. 39, 107-117. doi:10.1016/S0273-1223(98)00780-X 
Loveless, J.E., Painter, H.A., 1968. The influence of metal ion concentrations and $\mathrm{pH}$ value on the growth of a Nitrosomonas strain isolated from activated sludge. J. Gen. Microbiol. 52, 1-14. doi:10.1099/00221287-52$1-1$

Lytle, D.A., Sorg, T.J., Muhlen, C., Wang, L., Rahrig, M., French, K., 2007. Biological nitrification in a fullscale and pilot-scale iron removal drinking water treatment plant. J. Water Supply Res. Technol. 56, 125136. doi: $10.2166 /$ aqua.2007.092

Martens-Habbena, W., Stahl, D.A., 2011. Nitrogen metabolism and kinetics of ammonia-oxidizing archaea. Methods Enzymol. 496, 465-487. doi:10.1016/B978-0-12-386489-5.00019-1

Meincke, M., Bock, E., Kastrau, D., Kroneck, P.M.H., 1992. Nitrite oxidoreductase from Nitrobacter hamburgensis: redox centers and their catalytic role. Arch. Microbiol. 158, 127-131. doi:10.1007/BF00245215

Miljøministeriet, 2014. Statuary order on water quality and surveillance of water supply facilities. (In Danish; Bekendtgørelse om vandkvalitet og tilsyn med vandforsyningsanlæg). BEK nr 292 af 26/03/2014 Gældende. Danish Ministry of Environment

Pedroni, M., Davoli, D., Cavagnoli, G., Madoni, P., Cucchi, A., Rossi, F., 1997. Biological ammonium removal from drinking water: evaluation of water-plants performance. (In Italian; Rimozione biologica dell'ammoniaca dalle acque potabili: valutazione dei parametri di processo). IA Ing. Ambient. 26, 642-649.

Prosser, J.I., 1989. Autotrophic nitrification in bacteria, in: Rose, A.H., Tempest, D.W. (Eds.), Advances in microbial physiology. Academic Press, 125-181.

Rittmann, B.E., Tang, Y., Meyer, K., Bellamy, W.D., 2012. Biological processes. Chpt. 17 in Water Treatment Plant Design. American Water Works Association. 
544 Sanchez, I., Lee, G., 1973. Sorption of copper on Lake Monona sediments - effect of NTA on copper release from sediments. Water Res. 7, 587-593. doi:10.1016/0043-1354(73)90058-4

546 Sayavedra-Soto, L.A., Arp, D.J., 2011. Ammonia-oxidizing bacteria: Their biochemistry and molecular biology, 547 in: Ward, B.B., Arp, D.J., Klotz, M.G. (Eds.), Nitrification. ASM Press, Washington, DC, 11-37.

548 Simpson, D., 2008. Biofilm processes in biologically active carbon water purification. Water Res. 42, 2839$549 \quad 2848$. doi:10.1016/j.watres.2008.02.025

550 Sylva, R., 1976. The environmental chemistry of copper (II) in aquatic systems. Water Res. 10, 789-792. doi:10.1016/0043-1354(76)90097-X

Tatari, K., Smets, B.F., Albrechtsen, H.-J., 2013. A novel bench-scale column assay to investigate site-specific nitrification biokinetics in biological rapid sand filters. Water Res. 47, 6380-6387. doi:10.1016/j.watres.2013.08.005

USEPA, 2007a. Microwave assisted acid digestion of sediments, sludges, soils, and oils, EPA 3051A. USEPA Off. Res. Dev. Washingt.

USEPA, 2007b. Inductively Coupled Plasma-Mass Spectometry, EPA 6020A. USEPA Off. Res. Dev. Washingt.

558 Verhagen, F.J.M., Laanbroek, H.J., 1991. Competition for ammonium between nitrifying and heterotrophic bacteria in dual energy-limited chemostats. Appl. Envir. Microbiol. 57, 3255-3263. selected Swiss lakes and rivers. Aquat. Sci. 58, 69-87. doi:10.1007/BF00877641 
563 Zhang, Y., Edwards, M., 2010. Nutrients and metals effects on nitrification in drinking water systems. J. Am. 564 Water Work. Assoc. 102, 56-66.

565 Zhang, Y., Love, N., Edwards, M., 2009. Nitrification in drinking water systems. Crit. Rev. Environ. Sci. 566 Technol. 39, 153-208. doi:10.1080/10643380701631739 